\section{OPEN ACCESS}

Edited by: Jaime Ibáñez Quintana, University of Burgos, Spain

Reviewed by:

Elisabete dos Santos Freire, Universidade São Judas Tadeu, Brazi Balwant Singh,

Partap College of Education, India

*Correspondence:

Marlene Kollmayer

marlene.kollmayer@univie.ac.at

Specialty section:

This article was submitted to

Teacher Education a section of the journal

Frontiers in Education

Received: 18 May 2020

Accepted: 06 July 2020

Published: 31 July 2020

Citation:

Kollmayer M, Schultes $M-T$, Lüftenegger $M$, Finsterwald $M$, Spiel $C$ and Schober B (2020)

REFLECT - A Teacher Training

Program to Promote Gender Equality in Schools. Front. Educ. 5:136. doi: 10.3389/feduc.2020.00136

\title{
REFLECT - A Teacher Training Program to Promote Gender Equality in Schools
}

\section{Marlene Kollmayer ${ }^{1 *}$, Marie-Therese Schultes ${ }^{1}$, Marko Lüftenegger ${ }^{1,2}$, Monika Finsterwald ${ }^{1}$, Christiane Spiel ${ }^{1}$ and Barbara Schober ${ }^{1}$}

'Department of Developmental and Education Psychology, Faculty of Psychology, University of Vienna, Vienna, Austria,

${ }^{2}$ Department of Teacher Education, Centre for Teacher Education, University of Vienna, Vienna, Austria

Despite formally equal educational opportunities for women and men, educational and occupational careers are still characterized by gender disparities rather than gender equality. Men are overrepresented in STEM fields and higher positions, while women are frequently working in low-status jobs in the health and social sector. These differences already emerge during school time, when girls report lower academic self-concepts in STEM subjects than boys even after achievement is controlled for while the same is true for boys' self-concepts in reading and languages. Gender stereotypes that are conveyed by socializing agents are assumed to play an important role in maintaining gender differences in education. Teachers are important starting points for promoting gender equality in education as their attitudes and instructional practices are known to influence students' motivation and performance substantially. To promote girls and boys equally in coeducational settings, teachers have to reflect on their own gender stereotypes. Moreover, they require knowledge about gender differences in education and about teaching methods to foster the motivation of all students regardless of their gender. However, gender stereotypes are rarely dealt with in general teacher education and training programs that build teachers' competences for reflective coeducation are sparse. Against this backdrop, we present the teacher training program REFLECT that was developed to foster secondary school teachers' competences for supporting students in developing their individual potentials without being restricted by gender stereotypes. REFLECT is theoretically based on the systemic actiotope model and aims to expand teachers' objective action repertoire (knowledge, teaching methods) as well as their subjective action space (self-efficacy beliefs, implicit theories). The results of a pilot study show the effectiveness of REFLECT. Teachers' objective action repertoire and subjective action space for promoting boys and girls equally increased, as did students' knowledge of gender differences and perception of diversity fairness in the classroom. Implementing the contents of REFLECT in general teacher education could contribute to sustainably achieving gender equality in education.

Keywords: gender equality, education, gender stereotypes, reflective coeducation, teacher training 


\section{INTRODUCTION}

Despite formally equal educational opportunities for women and men, there are still massive gender differences in students' academic motivation and achievement that flow into gendertyped educational and occupational aspirations (Kollmayer et al., 2018a). Women are still underrepresented in science, technology, engineering, and mathematics (STEM) while men are underrepresented in health and other socially oriented sectors (Boniol et al., 2019; European Commission, 2019). This underrepresentation starts at school where girls report lower academic self-concepts in STEM subjects than boys even after achievement is controlled for while the same is true for boys' selfconcepts in reading and languages (Wigfield et al., 2002; Meece et al., 2006). In general, gender differences in motivation and achievement tend to be small in early childhood and the first school years but become increasingly apparent in adolescence (Evans et al., 2002; Hyde, 2005). Moreover, gender differences vary depending on the context of their investigation (Hyde, 2005) which indicates that socialization practices can minimize or exaggerate genuine gender differences.

Expectancy-value theory is one of the most influential theories for explaining human motivation and achievement. The theory postulates that an individual's achievement and achievementrelated choices can be explained by their expectations about how well they will do on a certain activity and the extent to which they value the activity (Wigfield and Eccles, 2000). Drawing on this, gender differences in expectations for success and values of certain tasks and domains were found to be related to gender stereotypes conveyed by parents and teachers (Jussim et al., 1996; Wang and Degol, 2013). Gender stereotypes are culturally shared assumptions about the typical characteristics of women and men or girls and boys (Ashmore and Boca, 1979; Kite et al., 2008). Men and women are assumed to differ in terms of achievement-oriented traits labeled as agency, competence, instrumentality, and in terms of social- and service-oriented traits labeled as communion, warmth, or expressivity. These assumptions correspond to traditional gender roles that expect men to be strong, aggressive and assertive, and women to be nurturing, polite, and beautiful. Regarding educational domains, STEM subjects are gender-typed as masculine while languages are gender-typed as feminine (Ceci and Williams, 2007, 2010; Steffens and Jelenec, 2011).

Teachers are an important starting point for promoting gender equity at school as their gender stereotyped beliefs and educational practices were found to influence gender differences in students substantially (Gunderson et al., 2012; Heyder et al., 2020). Tiedemann (2000) found elementary teachers to think that average achieving girls were less talented than equally achieving boys. Moreover, teachers were found to attribute girls' unexpected failure more to low ability and less to lack of effort than boys' unexpected failure (Fennema et al., 1990). Regarding classroom interactions, boys were found to receive more praise and critical feedback from teachers and to be given more time to talk in classrooms than girls (Sadker et al., 1991). Therefore, it is not surprising that teachers' gender stereotypes relate to their students' academic self-concepts. For example, boys have lower academic self-concepts and performance in reading if their teachers have gender stereotypical expectations regarding reading skills (Retelsdorf et al., 2015; Wolter et al., 2015; Muntoni and Retelsdorf, 2018). Similar relationships have been found between teachers' gender stereotypes and girls' academic selfconcept and performance in mathematics (Tiedemann, 2000; Steinmayr et al., 2019). In addition, teachers' gender stereotypes seem to impact their students' educational careers through transitional recommendations. Teachers with more pronounced gender stereotypes tend to recommend boys to mathematics and science-oriented secondary schools and girls to languageoriented schools (Nürnberger et al., 2016) which sets the course for gender-stereotyped career choices.

In summary, teachers seem to lack effective strategies to counteract the often-unwanted maintenance of gender stereotypes in their teaching as this topic is rarely dealt with in regular teacher training (Gray and Leith, 2004). Most interventions to reduce gender stereotypes in schools directly target students (Lamb et al., 2009; Brinkman et al., 2011) and focus exclusively on the promotion of girls in STEM subjects (Good et al., 2003; Zhao et al., 2018). However, training programs for teachers who work with hundreds of pupils in their professional lives and can thus act as multipliers are significantly more sustainable. Interestingly, Lüftenegger et al. (2012) found gender differences in motivation to decrease when teachers fostered aspects of individualization and autonomy in their classrooms. Teachers who choose to promote autonomy and individualization in their teaching seem to be less guided by unconscious gender stereotypes, but more mindful to their students' individual talents and needs. Concerning concrete classroom activities, promoting autonomy and individualization means to give each student the opportunity to choose tasks or learning settings that fit their interests and abilities. This fosters a positive motivational climate in which diversity is a normal phenomenon that a teacher is aware of, cares about and knows strategies for dealing with. In general, motivational support is seen as a central means of reducing gender differences at school (Lubinski et al., 2000; Ziegler et al., 2006).

\section{PEDAGOGICAL FRAMEWORK AND PRINCIPLES OF REFLECT}

The training program REFLECT aims at promoting secondary school teachers' competences for reflective coeducation (Faulstich-Wieland, 1994) by teaching them to design tuition in a way that enables girls and boys to develop their interests and competences together without being restricted by gender stereotypes (Finsterwald et al., 2014). The basic idea of reflective coeducation is that mixed-sex schooling can only be successful if teachers permanently reflect on their own gender stereotypes, examine whether their attitudes, and teaching practices stabilize existing gender relations and further develop their teaching competences (Horstkemper and Faulstich-Wieland, 1996). Thus, the training program REFLECT focuses on how teachers can succeed in promoting individual motivation and achievement in all students without being restricted by gender stereotypes. 
REFLECT is theoretically based on the actiotope model that explains human actions based on system theory (Ziegler et al., 2006, 2011) see Figure 1. An individual's actiotope consists of four interacting components: environment, goals, action repertoire, and subjective action space. The environment represents the material and symbolic framework for an individual's goal-oriented actions. The action repertoire includes all actions an individual is theoretically capable of performing, and the action repertoire actually used by an individual is designated as his/her current action repertoire. A person's subjective action space contains all behavior he/she perceives as feasible for himself/herself. Thus, according to the actiotope model, the process of transforming the current situation into a desired future state is regulated by the individual's action repertoire, subjective action space and the behavior options given in a specific environment. A teacher's environment is constituted by the students, the school's equipment, the colleagues and the headmaster. A teacher's current action repertoire includes his or her professional knowledge and set of actually applied teaching methods. Teachers' assumptions about the variability of gender differences as well as their self-efficacy beliefs to make a difference through teaching constitute their subjective action space.

In the training program REFLECT, four didactic principles were systematically applied: (1) Promoting the acquisition of various types of knowledge, namely declarative, procedural, contextual, and metacognitive knowledge (De Jong and Ferguson-Hessler, 1996). Teachers are guided to reflect on their own implicit assumptions and to come up with concrete applications of the training contents in their daily work life. (2) Designing the training modules according to principles of instructional psychology that have been shown to be effective in teacher trainings (Schober et al., 2007; Finsterwald et al., 2013; Lüftenegger et al., 2016). Every module contains teaching steps to attract attention, inform the participants about the learning goals, activate prior knowledge, illustrate the significance of the learning contents, offer guidance while learning, and secure

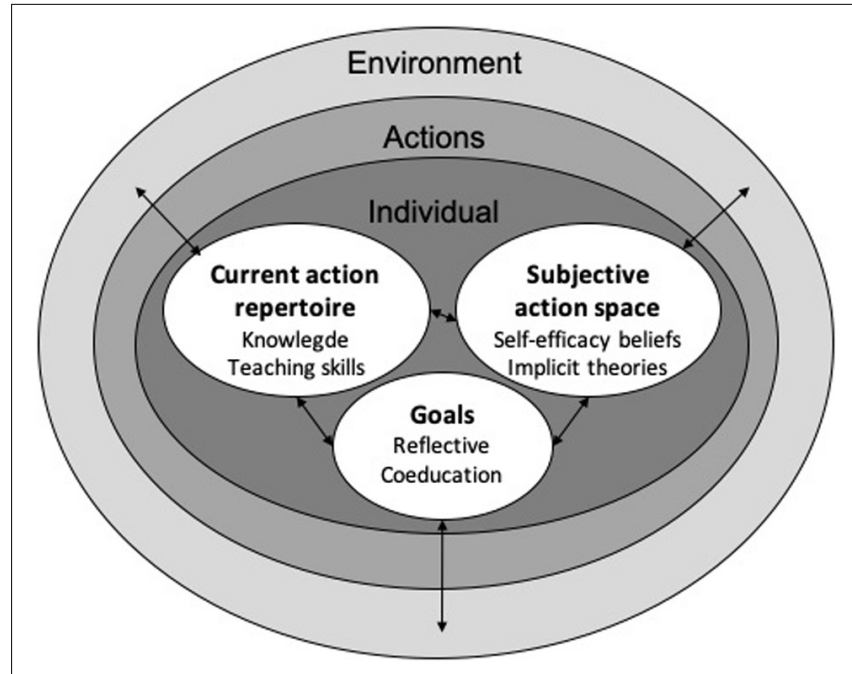

FIGURE 1 | The actiotope model. retention and transfer (Klauer, 1985). (3) Ensuring transfer following the anchored instruction approach (Bransford et al., 1990). Teachers work with authentic learning situations and are encouraged to test the training contents in their lessons. In each module, time is reserved for the teachers to exchange their experiences and discuss difficulties. Moreover, the second phase of the training is dedicated to transferring the training contents into teachers' classrooms. (4) Imparting the learning contents explicitly and implicitly. During the training, the teachers explicitly learn how to foster individualization and autonomy in their classrooms while the trainers themselves apply these teaching methods for implicit mediation.

\section{LEARNING ENVIRONMENT, OBJECTIVES AND PEDAGOGICAL FORMAT}

REFLECT focuses on teachers' actiotope for promoting gender equality in their classrooms by realizing the principles of reflective coeducation. Therefore, teachers learn about scientific findings on the emergence and maintenance of gender differences in academic motivation, achievement and aspirations, and about possibilities to reduce these gender differences through appropriate teaching methods in order to expand their current action repertoires. As teachers will only apply the acquired knowledge if they are convinced that they can implement it, their subjective action space is enlarged in the training through practical exercises and the supervised implementation of a classroom project. Teachers' environment flows into REFLECT as the teachers test all training contents in the classroom and discuss their experiences in the training. Moreover, the training addresses the role of language, textbooks, colleagues, and students' parents as relevant aspects of their environment. Although REFLECT is a teacher training program, it also aims at students. The intended changes in teachers' actiotopes are assumed to lead to changes in their teaching which in turn should lead to changes in their students. Therefore, REFLECT has three interrelated training goals: (1) Expanding secondary school teachers' current action repertoire by providing them with the knowledge necessary to change their teaching according to the principles of reflective coeducation; (2) Expanding teachers' subjective action space by enhancing their self-efficacy beliefs regarding reflective coeducation; (3) Increasing students' knowledge about the emergence of gender differences and improving their perception of diversity fairness in class.

The training program is conducted within the framework of a two-semester course. It is divided into two consecutive phases, an intensive phase followed by a supervision phase. For the participating teachers REFLECT embraces a work effort of $100 \mathrm{~h}$ per phase. In the intensive phase, teachers attend four modules of 2 days (à $7 \mathrm{~h}$ ) in a university setting (56 h). In the remaining $44 \mathrm{~h}$ of this phase, participants work with the training contents in preparation and follow-up processing between the modules. In the second semester during the supervision phase, teachers integrate the contents of the training into their teaching with the support of the trainers that is 


\section{Module 3: How to Create a Gender Equity Game in Class}

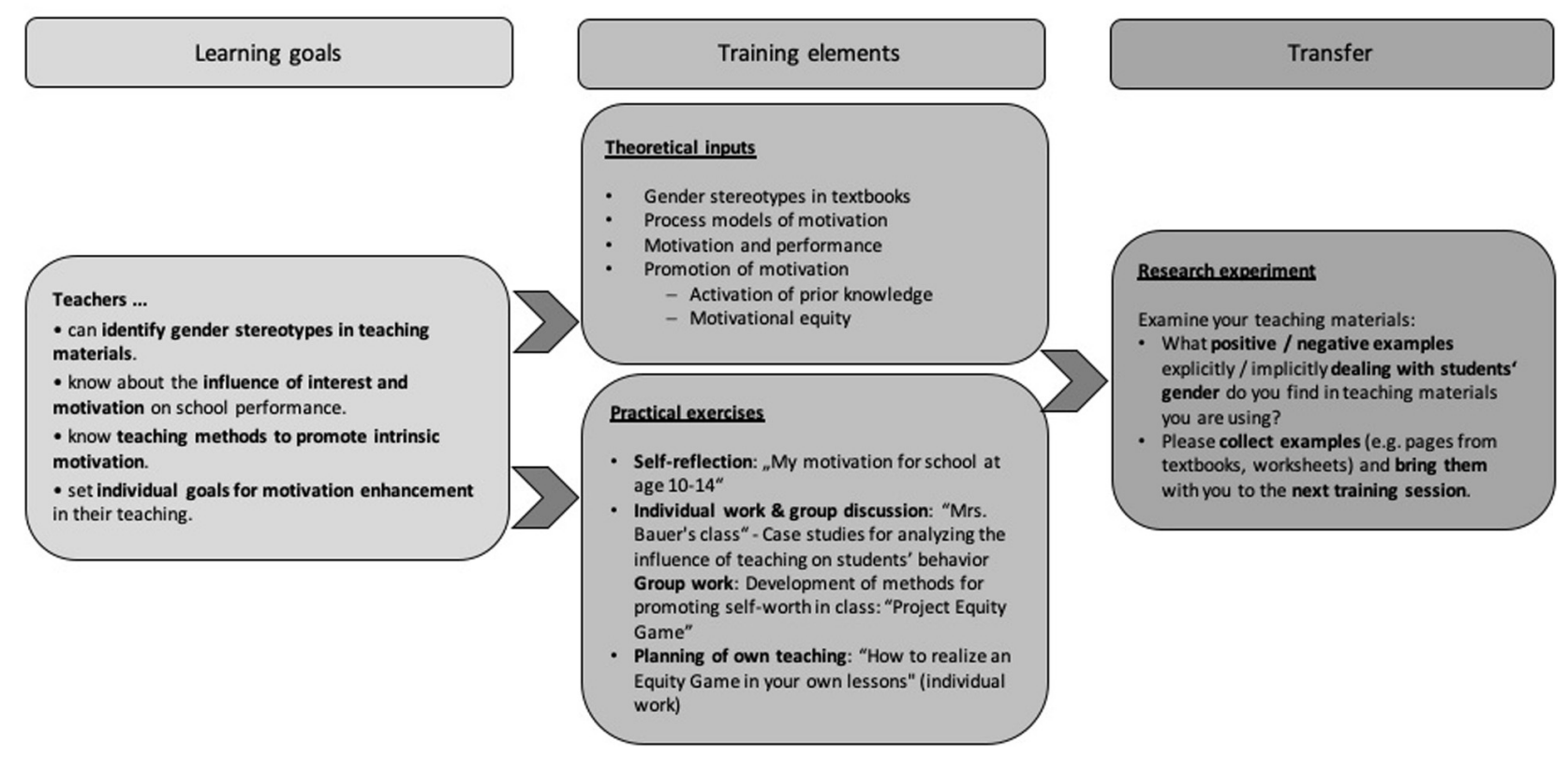

FIGURE 2 | Training goals and contents of Module 3.

fading in accordance with the cognitive apprenticeship method (Collins et al., 1989). Training contents in the intensive phase cover an introduction to the topic of reflective coeducation (Module 1), psychological findings regarding gender differences in education (Module 2), and concrete teaching methods to reduce gender differences in the classroom (Modules 3 and 4). In the first module, the participating teachers get to know different psychological approaches to the topic of promoting gender equity in schools including the comparison of singlesex education and reflective coeducation. In addition, they are guided in reflecting on their own gender stereotypes, which is an important prerequisite for reflective coeducation. The second module deals with the development of gender differences emphasizing the nature versus nurture debate (Eagly and Wood, 2013). The main focus of the module is on the contribution of gender stereotyped socialization practices to gender development and differentiation (Bussey and Bandura, 1999). Among others, the module emphasizes the influence of parents, teachers, media, and language use (Kollmayer et al., 2018b). Based on this, teachers are guided to reflect on their impact on the emergence of gender differences among their students. In the third module, teachers learn to identify aspects of their teaching that can lead to the development of gender-typed academic motivation, achievement and aspirations in their students, and about ways of promoting gender equity in the classroom, for example by selecting adequate teaching materials or assigning tasks differently. The module especially focuses on how to create a climate of motivational equity, in which students are motivated to learn primarily for intrinsic reasons (Covington, 1998). Building on that, teachers are guided in designing lessons that foster individualization and autonomy and thus reduce the impact of gender stereotypes on motivation and achievement (Lüftenegger et al., 2012). Figure 2 highlights how the different elements of the training (theoretical input, practical exercises, and research experiments) interact to support the teachers in reaching the learning goals of the third module as an example for the general structure of the training. In the fourth module, REFLECT deals with the importance of attributions, i.e., assigning causes to success and failure for academic motivation and achievement (Weiner, 1985). Teachers learn about typical gender differences in attributions for academic success and failure and about related feedback behavior of teachers (Fennema et al., 1990; Sadker et al., 1991). They practice how to give students attributional feedback that strengthens their individual motivation regardless of their gender. In addition, options for implementing reflective coeducation at the school level are discussed, e.g., representing this principle in conversation with headmasters, colleagues, and parents.

The intensive phase of REFLECT is followed by a supervision phase to ensure that the teachers integrate the training contents into their daily work routines. In this phase, the teachers are supervised in developing and conducting individual class projects dealing with the topic of "Gender and Occupation," as gender differences in secondary school students often flow into gendertyped career choices (OECD, 2012). Teachers are encouraged to design their class projects to suit the subjects they usually teach. Each teacher is bound to spend at least 10 lessons for at least 5 weeks on the class project, since programs were found to have significant effects only after a longer implementation phase (Lipowsky and Rzejak, 2012). The class projects include teaching students about the fact that girls and boys do not systematically differ in their aptitudes for different occupations, reflecting on reasons for differences in career choices, and discussing society's 
gender (in)equality. The teachers are supported in designing the class projects in line with the teaching methods they get to know in the intensive phase.

\section{EVALUATION RESULTS}

In a pilot study with 38 teachers who participated in REFLECT and their 564 students, the effectivity of the training program was systematically evaluated. The evaluation was carried out by means of a training-control-group design with a multimethod, multi-informant approach using pre- and posttest data. Teachers and students completed different quantitative (knowledge tests; questionnaires with closed answer format) and qualitative instruments (research logbook, portfolios). Both the training group and the control group were surveyed at the beginning and shortly after completion of the project with selfreport online questionnaires. Detailed information about the data collection, methods, and results of the evaluation of the training program can be found in two original research articles dealing exclusively with the evaluation of REFLECT - Kollmayer et al. (2019) for teachers and Schultes et al. (2015) for students.

As indicators for teachers' current action repertoire, we assessed their knowledge of gender differences in education using multiple choice questions as well as their use of teaching methods promoting autonomy (Jerusalem et al., 2009). The multiplechoice questions were analyzed in a way that minimized the probability of guessing the right result (Kubinger, 2014). One point was awarded if a question was answered completely correct (i.e., if all correct alternatives and no false alternatives were selected), in any other case, zero points were awarded. As indicators for teachers' subjective action space, their self-efficacy for motivation enhancement (Bandura, 1997) as well as their implicit theories about gender differences (Dweck et al., 1995) were assessed. In addition, the online questionnaire contained questions regarding teachers' demographic characteristics (e.g., gender, age, years of service) and a shortened form of the modern sexism scale (Eckes and Six-Materna, 1998). The teachers answered all questions on sliders with a marked middle from 0 (not at all convinced) to 100 (fully convinced). Sample items and reliabilities of the scales are shown in Table $\mathbf{1 .}$

The 38 teachers of the training group were matched with 76 teachers of the control group (consisting of 121 teachers in total) using propensity score matching (Lee and Little, 2017). In quasiexperimental intervention designs, propensity score matching minimizes effects caused by non-controllable confounding variables. In order to determine relevant matching criteria, we analyzed differences between the two groups at the first measurement point. We detected significant differences between the training group and the control group regarding teachers' sexist attitudes (Eckes and Six-Materna, 1998) and regarding the extent to which teachers already promoted autonomy in their classrooms, indicating that teachers who participated in the training program REFLECT were less sexist and promoted autonomy to a greater extent than their colleagues who did not participate in REFLECT. To account for these differences, we matched participants of the two groups according to similarity in these variables, as well as their proximity in gender and age. The results of the evaluation show the effectiveness of the training program REFLECT (Kollmayer et al., 2019). In comparison to the control group, REFLECT teachers' current action repertoire and subjective action space showed a stronger increase. More

TABLE 1 | Sample items and reliabilities of the questionnaires used in the evaluation of REFLECT.

\begin{tabular}{|c|c|c|c|c|c|}
\hline \multirow[t]{2}{*}{ Target group } & \multirow[t]{2}{*}{ Scale } & \multirow[t]{2}{*}{ Sample item } & \multirow{2}{*}{$\begin{array}{l}\text { Number of } \\
\text { items }\end{array}$} & \multicolumn{2}{|c|}{ Cronbach's alpha } \\
\hline & & & & Pretest & Posttest \\
\hline \multirow[t]{5}{*}{ Teachers } & $\begin{array}{l}\text { Teaching self-efficacy (adapted from Bandura, } \\
\text { 1997) }\end{array}$ & $\begin{array}{l}\text { To what extent can you ensure that your students believe } \\
\text { they can be good at school? }\end{array}$ & 4 & 0.80 & 0.86 \\
\hline & $\begin{array}{l}\text { Implicit theories about gender differences } \\
\text { (adapted from Dweck et al., 1995) }\end{array}$ & Gender differences in performance cannot be changed. & 3 & 0.80 & 0.80 \\
\hline & $\begin{array}{l}\text { Use of teaching methods promoting autonomy } \\
\text { (Jerusalem et al., 2009) }\end{array}$ & In my class, the students can choose from various topics. & 5 & 0.79 & 0.88 \\
\hline & $\begin{array}{l}\text { Knowledge of gender differences } \\
\text { (self-constructed) }\end{array}$ & $\begin{array}{l}\text { When they have the same school performance; (a) male } \\
\text { students show a tendency to overestimate their } \\
\text { performance. (true); (b) female students show a tendency to } \\
\text { underestimate their performance. (true); (c) male students } \\
\text { show a tendency to underestimate their performance. } \\
\text { (false); (d) female students show a tendency to overestimate } \\
\text { their performance. (false) }\end{array}$ & 9 & - & - \\
\hline & Modern Sexism (Eckes and Six-Materna, 1998) & $\begin{array}{l}\text { It is rare to see women treated in a sexist manner on } \\
\text { television. }\end{array}$ & 6 & 0.80 & 0.76 \\
\hline \multirow[t]{3}{*}{ Students } & $\begin{array}{l}\text { Perception of diversity fairness in the classroom } \\
\text { (Schober et al., 2007) }\end{array}$ & $\begin{array}{l}\text { In our class those girls who do not behave like "typical girls" } \\
\text { are also popular. }\end{array}$ & 7 & 0.64 & 0.72 \\
\hline & $\begin{array}{l}\text { Ratings of intervention fidelity (Rakoczy et al., } \\
\text { 2008) }\end{array}$ & In the project, I could choose between different tasks. & 14 & - & 0.80 \\
\hline & Knowledge of gender issues (self-constructed) & $\begin{array}{l}\text { In Austria men are allowed to work as kindergarten } \\
\text { teachers (true). }\end{array}$ & 9 & - & - \\
\hline
\end{tabular}


concretely, over the duration of the training program, trained teachers showed a higher increase in their knowledge about gender differences in education and also a higher increase in promoting students' autonomy in the classroom (= current action repertoire). Moreover, regarding teachers' subjective action space, REFLECT led to a higher increase in teachers' self-efficacy beliefs for enhancing students' motivation and to a stronger decrease in teachers' beliefs that gender differences are unchangeable.

The effectiveness of REFLECT on the part of the students was analyzed in combination with the teachers' fidelity in implementing their class projects during the supervision phase (for details, see Schultes et al., 2015). Teachers had documented their class projects in portfolios, which were rated by two independent experts concerning intervention fidelity to the didactic principles of reflective coeducation. Participating students $(N=564)$ were surveyed on their knowledge about gender issues using single-choice questions (wrong/false) and on their perception of diversity fairness in the classroom (Schober et al., 2007) at a pre- and posttest. Moreover, they also rated the intervention fidelity of the class projects (Rakoczy et al., 2008). Changes in outcome variables were tested using latent change modeling, and experts' and students' ratings of intervention fidelity were linked to outcomes in students using hierarchical linear modeling. The results showed that the students' knowledge about gender issues increased during the program. When the teachers had implemented the class projects as intended, there was also an increase in students' perception of diversity fairness in the classroom. Sample items and reliabilities of the scales are shown in Table 1.

\section{DISCUSSION}

The training program REFLECT focuses on imparting reflective coeducation in secondary schools, where students' gender-typed academic motivation and occupational aspirations develop under the influence of teachers. Reflective coeducation requires teachers to reflect on their own gender stereotypes, to examine whether their teaching is influenced by gender stereotypes, and to develop their teaching competences (Faulstich-Wieland, 1994). Training teachers is very sustainable as each teacher works with hundreds of students in his/her professional life. The results of the pilot study show that REFLECT not only made teachers see gender differences as less unchangeable, but also gave them confidence for promoting their students' motivation regardless of their gender. Moreover, REFLECT led to an increase in knowledge about gender differences in education and in the use of teaching methods to promote autonomy and individualization. Both aspects are central to reflective coeducation. Only teachers who know how to counteract existing gender stereotypes in their teaching and also believe that they are capable of changing gender differences will promote change.

Of course, secondary schools are not the only educational context where gender stereotypes are maintained. Interventions to promote gender equality must consider the peculiarities of different stages of human development and educational contexts. While students' academic motivation and occupational decisions are especially relevant topics to deal with for secondary school teachers, teachers in preschools have to focus on other topics for realizing reflective coeducation. Preschool teachers were found to project gender stereotypes about play onto their students (Lynch, 2015) which can result in gender-typed toy preferences in children. Gender-typed toy play in turn leads to the promotion of gender-typed skills, with girls practicing communal roles and boys practicing agentic roles (Li and Wong, 2016). Therefore, we also developed a training program for preschool teachers, in which they learn about children's gender development and differentiation, mechanisms and materials that perpetuate gender stereotypes in preschool settings, and how to create a less stereotypical environment that enables a greater range of interests and behaviors in children (Kollmayer et al., 2018c).

The pilot study showed that teachers voluntarily participating in REFLECT were less sexist and had already applied better teaching methods than the average teacher in the control group. Therefore, implementing reflective coeducation in general teacher education could contribute to achieving gender equity in education even more than training programs that reach primarily teachers who are already sensitized to issues of gender equality. However, transferring insights from research to policy and society is not trivial (Schober et al., 2016). Spiel et al. (2018) propose a six-step procedure for implementing intervention research into public policy, that includes mission-driven problem recognition, ensuring availability of robust scientific knowledge, identification of reasonable starting points for action, establishment of a cooperation process with policymakers, coordinated development of intervention, and transfer of program implementation. Following these steps, the REFLECT program was developed with the support of five Austrian federal ministries. However, even after successful piloting, the contents of the training program were not implemented in general teacher education. This shows the challenges involved in linking the systems of politics and science that still have to be overcome.

\section{DATA AVAILABILITY STATEMENT}

The raw data supporting the conclusions of this article will be made available by the authors, without undue reservation.

\section{ETHICS STATEMENT}

Ethical review and approval was not required for the study on human participants in accordance with the local legislation and institutional requirements. Written informed consent to participate in this study was provided by the participants' legal guardian/next of kin.

\section{AUTHOR CONTRIBUTIONS}

MF, BS, and CS developed the training program. MK and M-TS prepared the draft manuscript. MF, ML, and CS provided critical revisions. All authors contributed meaningfully 
to the manuscript and approved the final version of the manuscript for submission.

\section{FUNDING}

The publication of this article was supported by the open access funding provided by University of Vienna. The development

\section{REFERENCES}

Ashmore, R. D., and Boca, F. K. (1979). Sex stereotypes and implicit personality theory: toward a cognitive - social psychological conceptualization. Sex Roles 5, 219-248. doi: 10.1007/BF00287932

Bandura, A. (1997). Self-Efficacy: The Exercise Of Control. New York, NY: Freeman. Boniol, M., McIsaac, M., Xu, L., Wuliji, T., Diallo, K., and Campbell, J. (2019). Gender Equity In The Health Workforce: Analysis of 104 Countries (No. WHO/HIS/HWF/Gender/WP1/2019.1). Geneva: World Health Organization.

Bransford, J. D., Sherwood, R. D., Hasselbring, T. S., Kinzer, C. K., and Williams, S. M. (1990). "Anchored instruction: why we need it and how technology can help," in Cognition, Education, And Multimedia: Exploring Ideas In High Technology, eds D. Nix and R. J. Spiro (New Jersey: Lawrence Erlbaum Associates), 115-141.

Brinkman, B. G., Jedinak, A., Rosen, L. A., and Zimmerman, T. S. (2011). Teaching children fairness: decreasing gender prejudice among children. Analys. Soc. Issues Public Policy 11, 61-81. doi: 10.1111/j.1530-2415.2010.01222.x

Bussey, K., and Bandura, A. (1999). Social cognitive theory of gender development and differentiation. Psychol. Rev. 106, 676-713. doi: 10.1037/0033-295X.106.4. 676

Ceci, S. J., and Williams, W. M. (2007). Why Aren't More Women In Science: Top Researchers Debate The Evidence. Washington, DC: American Psychological Association.

Ceci, S. J., and Williams, W. M. (2010). Sex differences in math-intensive fields. Curr. Direct. Psychol. Sci. 19, 275-279. doi: 10.1177/0963721410383241

Collins, A., Brown, J. S., and Newman, S. E. (1989). "Cognitive apprenticeship: teaching the crafts of reading, writing, and mathematics," in Knowing, Learning, And Instruction: Essays In Honor Of Robert Glaser, ed. L. B. Resnick (New Jersey: Lawrence Erlbaum Associates), 453-494. doi: 10.4324/9781315044408-14

Covington, M. (1998). The Will To Learn: A Guide For Motivating Young People. Cambridge: Cambridge University Press.

De Jong, T., and Ferguson-Hessler, M. G. (1996). Types and qualities of knowledge. Educ. Psychol. 31, 105-113. doi: 10.1207/s15326985ep3102_2

Dweck, C. S., Chiu, C., and Hong, Y. (1995). Implicit theories and their role in judgments and reactions: a word from two perspectives. Psychol. Inq. 6, 267-285. doi: 10.1207/s15327965pli0604_1

Eagly, A. H., and Wood, W. (2013). The nature-nurture debates: 25 years of challenges in understanding the psychology of gender. Perspect. Psychol. Sci. 8, 340-357. doi: 10.1177/1745691613484767

Eckes, T., and Six-Materna, I. (1998). Leugnung von Diskriminierung: Eine Skala zur Erfassung des modernen Sexismus. Zeitschrift Für Sozialpsychol. 29, 224238.

European Commission (2019). She Figures 2018: Gender Equality In Research And Innovation In The European Union. Brussels: European Commission.

Evans, E. M., Schweingruber, H., and Stevenson, H. W. (2002). Gender differences in interest and knowledge acquisition: the United States, Taiwan and Japan. Sex Roles 47, 153-167. doi: 10.1023/A:1021047122532

Faulstich-Wieland, H. (1994). "Reflexive Koedukation. Zur Entwicklung der Koedukationsdebatte in den Bundesländern," in Geschlechterverhältnisse und die Pädagogik, eds U. Bracht and D. Keiner (Bern: Peter Lang), 325-342.

Fennema, E., Peterson, P. L., Carpenter, T. P., and Lubinski, C. A. (1990). Teachers' attributions and beliefs about girls, boys, and mathematics. Educ. Stud. Math. 21, 55-69. doi: 10.1007/BF00311015

Finsterwald, M., Schober, B., Jöstl, G., and Spiel, C. (2014). "Koedukation in der Schule, reflexive," in Dorsch - Lexikon der Psychologie, 18th Edn, ed. M. A. Wirtz (Göttingen: Hogrefe), 837. and piloting of the training program REFLECT was funded by the following Austrian federal ministries: Education, the Arts and Culture; Women and Public Service; Transport, Innovation, and Technology; Labor, Social Affairs, and Consumer Protection. The development and piloting of the training program for preschool teachers mentioned in the Discussion section was funded by the Austrian federal ministry for Family and Youth.

Finsterwald, M., Wagner, P., Schober, B., Lüftenegger, M., and Spiel, C. (2013). Fostering lifelong learning - Evaluation of a teacher education program for professional teachers. Teach. Teach. Educ. 29, 144-155. doi: 10.1016/j.tate.2012. 08.009

Good, C., Aronson, J., and Inzlicht, M. (2003). Improving adolescents' standardized test performance: an intervention to reduce the effects of stereotype threat. J. Appl. Dev. Psychol. 24, 645-662. doi: 10.1016/j.appdev.2003.09.002

Gray, C., and Leith, H. (2004). Perpetuating gender stereotypes in the classroom: a teacher perspective. Educ. Stud. 30, 3-17. doi: 10.1080/03055690320001 59705

Gunderson, E. A., Ramirez, G., Levine, S. C., and Beilock, S. L. (2012). The role of parents and teachers in the development of gender-related math attitudes. Sex Roles 66, 153-166. doi: 10.1007/s11199-011-9996-2

Heyder, A., Kessels, U., and Retelsdorf, J. (2020). Geschlechterstereotype in der Schule. Zeitschrift Für Entwicklungspsychol. Pädagogische Psychol. 51, 69-70. doi: 10.1026/0049-8637/a000209

Horstkemper, M., and Faulstich-Wieland, H. (1996). 100 Jahre Koedukationsdebatte- und kein Ende. Ethik Sozialwissenschaften 4, 509-520.

Hyde, J. S. (2005). The gender similarities hypothesis. Am. Psychol. 60, 581-592. doi: 10.1037/0003-066X.60.6.581

Jerusalem, M., Drossler, S., Kleine, D., Klein-Heßling, J., Mittag, W., and Roder, B. (2009). Skalenbuch: Förderung von Selbstwirksamkeit und Selbstbestimmung im Unterricht. Skalen zur Erfassung von Lehrer-Schülermerkmalen. Berlin: Humboldt-Universität zu Berlin.

Jussim, L., Eccles, J., and Madon, S. (1996). “Social perception, social stereotypes, and teacher expectations: accuracy and the quest for the powerful selffulfilling prophecy," in Advances in Experimental Social Psychology, Vol. 28, ed. M. P. Zanna (Cambridge, MA: Academic Press), 281-388. doi: 10.1016/s00652601(08)60240-3

Kite, M. E., Deaux, K., and Haines, E. L. (2008). “Gender stereotypes,” in Psychology of Women: A Handbook Of Issues And Theories, Vol. 2, eds F. L. Denmark and M. A. Paludi (Westport, CO: Praeger Publishers), 205-236.

Klauer, K. J. (1985). Framework for a theory of teaching. Teach. Teach. Educ. 1, 5-17. doi: 10.1016/0742-051X(85)90026-5

Kollmayer, M., Pfaffel, A., Schober, B., and Brandt, L. (2018a). Breaking away from the male stereotype of a specialist: gendered language affects performance in a thinking task. Front. Psychol. 9:985. doi: 10.3389/fpsyg.2018.00985

Kollmayer, M., Schober, B., and Spiel, C. (2018b). Gender stereotypes in education: development, consequences, and interventions. Eur. J. Dev. Psychol. 15, 361377. doi: 10.1080/17405629.2016.1193483

Kollmayer, M., Schultes, M.-T., Schober, B., Hodosi, T., and Spiel, C. (2018c). Parents' judgements about the desirability of toys for their children: associations with gender role attitudes, gender-typing of toys, and demographics. Sex Roles 79, 329-341. doi: 10.1007/s11199-017-0882-4

Kollmayer, M., Pfaffel, A., Schultes, M.-T., Lüftenegger, M., Finsterwald, M., Popper, V., et al. (2019). REFLECT - ein Interventionsprogramm zum Aufbau von Lehrkräftekompetenzen für reflexive Koedukation. Zeitschrift Für Entwicklungspsychol. Pädagogische Psychol. 51, 110-122. doi: 10.1026/0049$8637 / \mathrm{a} 000210$

Kubinger, K. D. (2014). Gutachten zur Erstellung “gerichtsfester” Multiple-ChoicePrüfungsaufgaben. Psychologische Rundschau 65, 169-178. doi: 10.1026/00333042/a000218

Lamb, L. M., Bigler, R. S., Liben, L. S., and Green, V. A. (2009). Teaching children to confront peers' sexist remarks: implications for theories of gender development and educational practice. Sex Roles 61, 361-382. doi: 10.1007/s11199-0099634-4 
Lee, J., and Little, T. D. (2017). A practical guide to propensity score analysis for applied clinical research. Behav. Res. Ther. 98, 76-90. doi: 10.1016/j.brat.2017. 01.005

Li, R. Y. H., and Wong, W. I. (2016). Gender-typed play and social abilities in boys and girls: are they related? Sex Roles 74, 399-410. doi: 10.1007/s11199016-0580-7

Lipowsky, F., and Rzejak, D. (2012). Lehrerinnen und Lehrer als Lerner Wann gelingt der Rollentausch? Merkmale und Wirkungen wirksamer Lehrkräftefortbildungen. Schulpädagogik Heute 5, 1-17.

Lubinski, D., Benbow, C. P., and Morelock, M. (2000). "Gender differences in engineering and the physical sciences among the gifted: an inorganic-organic distinction," in International Handbook For Research On Giftedness And Talent, eds K. A. Keller, F. J. Monks, R. J. Sternberg, and R. F. Subotnik (Amsterdam: Elsevier), 627-641.

Lüftenegger, M., Finsterwald, M., Klug, J., Bergsmann, E., van de Schoot, R., Schober, B., et al. (2016). Fostering pupils' lifelong learning competencies in the classroom: evaluation of a training programme using a multivariate multilevel growth curve approach. Eur. J. Dev. Psychol. 13, 719-736. doi: 10. 1080/17405629.2015.1077113

Lüftenegger, M., Schober, B., Van de Schoot, R., Wagner, P., Finsterwald, M., and Spiel, C. (2012). Lifelong learning as a goal - do autonomy and selfregulation in school result in well prepared pupils? Learn. Instruct. 22, 27-36. doi: 10.1016/j.learninstruc.2011.06.001

Lynch, M. (2015). Guys and dolls: a qualitative study of teachers' views of gendered play in kindergarten. Early Child Dev. Care 185, 679-693. doi: 10. 1080/03004430.2014.950260

Meece, J. L., Glienke, B. B., and Burg, S. (2006). Gender and motivation. J. Sch. Psychol. 44, 351-373. doi: 10.1016/j.jsp.2006.04.004

Muntoni, F., and Retelsdorf, J. (2018). Gender-specific teacher expectations in reading-The role of teachers' gender stereotypes. Contempor. Educ. Psychol. 54, 212-220. doi: 10.1016/j.cedpsych.2018.06.012

Nürnberger, M., Nerb, J., Schmitz, F., Keller, J., and Sütterlin, S. (2016). Implicit gender stereotypes and essentialist beliefs predict preservice teachers' tracking recommendations. J. Exper. Educ. 84, 152-174. doi: 10.1080/00220973.2015. 1027807

OECD (2012). Closing the Gender Gap. Act Now. Paris: OECD Publishing. doi: 10.1787/9789264179370-en

Rakoczy, K., Klieme, E., and Pauli, C. (2008). Die Bedeutung der wahrgenommenen Unterstützung motivationsrelevanter Bedürfnisse und des Alltagsbezugs im Mathematikunterricht für die selbstbestimmte Motivation. Zeitschrift Für Pädagogische Psychol. 22, 25-35. doi: 10.1024/1010-0652.22.1.25

Retelsdorf, J., Schwartz, K., and Asbrock, F. (2015). Michael can't read! Teachers' gender stereotypes and boys' reading self-concept. J. Educ. Psychol. 107, 186194. doi: 10.1037/a0037107

Sadker, M., Sadker, D., and Klein, S. (1991). The issue of gender in elementary and secondary education. Rev. Res. Educ. 17, 269-334. doi: 10.3102/ 0091732X017001269

Schober, B., Brandt, L., Kollmayer, M., and Spiel, C. (2016). Overcoming the ivory tower: transfer and societal responsibility as crucial aspects of the bildungpsychology approach. Eur. J. Dev. Psychol. 13, 636-651. doi: 10.1080/17405629. 2016.1231061

Schober, B., Finsterwald, M., Wagner, P., Lüftenegger, M., Aysner, M., and Spiel, C. (2007). TALK-A training program to encourage lifelong learning in school. Zeitschrift Für Psychologie 215, 183-193. doi: 10.1027/0044-3409.215.3.183

Schultes, M.-T., Jöstl, G., Finsterwald, M., Schober, B., and Spiel, C. (2015). Measuring intervention fidelity from different perspectives with multiple methods: the reflect program as an example. Stud. Educ. Eval. 47, 102-112. doi: 10.1016/j.stueduc.2015.10.001

Spiel, C., Schober, B., and Strohmeier, D. (2018). Implementing intervention research into public policy - the 'I3-approach'. Prev. Sci. 19, 337-346. doi: 10.1007/s11121-016-0638-3

Steffens, M. C., and Jelenec, P. (2011). Separating implicit gender stereotypes regarding math and language: implicit ability stereotypes are self-serving for boys and men, but not for girls and women. Sex Roles 64, 324-335. doi: 10. 1007/s11199-010-9924-x

Steinmayr, R., Weidinger, A. F., Heyder, A., and Bergold, S. (2019). Warum schätzen Mädchen ihre mathematischen Kompetenzen geringer ein als Jungen? Zeitschrift Für Entwicklungspsychol. Pädagogische Psychol. 51, 71-83. doi: 10. 1026/0049-8637/a000213

Tiedemann, J. (2000). Parents' gender stereotypes and teachers' beliefs as predictors of children's concept of their mathematical ability in elementary school. J. Educ. Psychol. 92:144. doi: 10.1037/0022-0663.92.1.144

Wang, M.-T., and Degol, J. (2013). Motivational pathways to STEM career choices: using expectancy-value perspective to understand individual and gender differences in STEM fields. Dev. Rev. 33, 304-340. doi: 10.1016/j.dr.2013. 08.001

Weiner, B. (1985). An attributional theory of achievement motivation and emotion. Psychol. Rev. 92, 548-573. doi: 10.1037/0033-295X.92.4.548

Wigfield, A., Battle, A., Keller, L. B., and Eccles, J. S. (2002). "Sex differences in motivation, self-concept, career aspiration, and career choice: implications for cognitive development," in Advances in Applied Developmental Psychology, Vol. 21. Biology, Society, And Behavior: The Development of Sex Differences In Cognition, eds A. McGillicuddy-De Lisi and R. De Lisi (Norwood, NJ: Ablex Publishing), 93-124.

Wigfield, A., and Eccles, J. S. (2000). Expectancy-value theory of achievement motivation. Contemp. Educ. Psychol. 25, 68-81. doi: 10.1007/BF02209024

Wolter, I., Braun, E., and Hannover, B. (2015). Reading is for girls!? The negative impact of preschool teachers' traditional gender role attitudes on boys' reading related motivation and skills. Front. Psychol. 6:1267. doi: 10.3389/fpsyg.2015. 01267

Zhao, F., Zhang, Y., Alterman, V., Zhang, B., and Yu, G. (2018). Can math-gender stereotypes be reduced? A theory-based intervention program with adolescent girls. Curr. Psychol. 37, 612-624. doi: 10.1007/s12144-016-9543-y

Ziegler, A., Heller, K. A., Schober, B., and Dresel, M. (2006). "The actiotope: a heuristic model for the development of a research program designed to examine and reduce adverse motivational conditions influencing scholastic achievement," in Knowledge And Action, eds D. Frey, H. Mandl, and L. V. Rosenstiel (Boston, MA: Hogrefe \& Huber Publishers), 143-173.

Ziegler, A., Stoeger, H., and Grassinger, R. (2011). Actiotope model and selfregulated learning. Psychol. Test Assessm. Model. 53, 161-179.

Conflict of Interest: The authors declare that the research was conducted in the absence of any commercial or financial relationships that could be construed as a potential conflict of interest.

Copyright (c) 2020 Kollmayer, Schultes, Lüftenegger, Finsterwald, Spiel and Schober. This is an open-access article distributed under the terms of the Creative Commons Attribution License (CC BY). The use, distribution or reproduction in other forums is permitted, provided the original author(s) and the copyright owner(s) are credited and that the original publication in this journal is cited, in accordance with accepted academic practice. No use, distribution or reproduction is permitted which does not comply with these terms. 